\title{
Contents Vol. 6, 1995
}

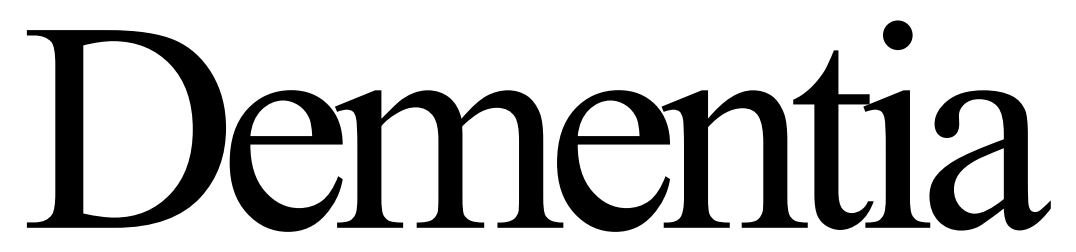

\section{Editor-in-Chief}

V. Chan-Palay, New York, N.Y. 


\section{Editorial Board}

L. Amaducci, Florence

MJ. Ball, Portland, Oreg.

K. Beyreuter, Heidelberg

A. Brun, Lund

S.H. Ferris, New York, N.Y.

CG. Gottfries, Mölndal

L. Gustafson, Lund

K. Hasegawa, Kawasaki

I. Hanin, Maywood, 111.

F.F. Hefti, San Francisco, Calif.

A.S. Henderson, Canberra

S. Hirai, Gummaken

F. Javoy-Agid, Paris

A.D. Korczyn, Tel Aviv

MJ. de Leon, New York, N.Y. 
C.L. Masters, Melbourne R. Mayeux, New York, N.Y. E. Melamed, Petah-Tiqva D.L. Murphy, Bethesda, Md. D.S. Olton, Baltimore, Md. E.K. Perry, Newcastle uponTyne J.W. Pettegrew, Pittsburgh, Pa. D. Price, Baltimore, Md. J. Rogers, Sun City, Ariz. A.D. Roses, Durham, N.C. M. Roth, Cambridge Y. Sakaki, Fukuokashi H.M. Wisniewski,

Staten Island, N.Y M. Yoshida, Tochigi

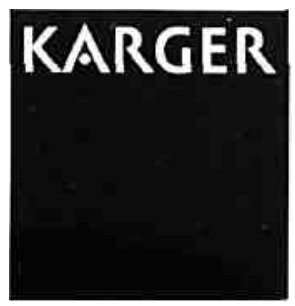


Contents Vol. 6,1995

No. 1 


\section{Original Research Articles}

Neuronal Ultrastructural Abnormalities in a Patient with 1

Frontotemporal Dementia and Motor Neuron Disease Chang, L.; Cornfbrd, M.; Miller, B.L.; Itabashi, H.; Mcna, I.

Cell-Cycle-Dependent Abnormal Calcium Response in Fibro- $\quad 9$ blasts from Patients with Familial Alzheimer's Disease Tatebayashi, Y.; Takcda, M.; Kashiwagi, Y.; Okochi, M.;

Kurumadani, T.; Sekiyama, A.; Kanayama, G.; Hariguchi, S.; Nishimura, T.

Elevated AIphai-Antichymotrypsin Serum Levels in a Subset

of Nondemented First-Degree Relatives of Alzheimer's

Disease Patients

Altstiel, L.D.; Lawlor, B.; Mohs, R.; Schmeidler, J.; Dalton, A.;

Mehta, P.; Davis, K.

Relative Roles of Plaques and Tangles in the Dementia of

Alzheimer's Disease: Correlations Using Three Sets of Neuropathological Criteria

Nagy, Zs.; Esiri, M.M.; Jobst, K.A.; Morris, J.H.; King, E.M.-F.; McDonald, B.; Litchfield, S.; Smith, A; Bametson, L; Smith, A.D.

Correlations between Cognitive Impairment, Middle Cerebral 32 Artery Flow Velocity and Cortical Glucose Metabolism in the Early Phase of Alzheimers Disease

Franceschi, M.; Alberoni, M.; Bressi, S.; Canal, N.; Comi, G.; Fazio, F.; Grassi, F.; Perani, D.; Volonte, MA

Chronic Obstructive Pulmonary Disease and Associated

39

Pattems of Memory Decline

Fioravanti, M.; Nacca, D.; Amati, S.; Buckley, A.E.; Bisetti, A.

Visuospatial Performance in Very Old Demented Persons:

49

An Individual DifFerence Analysis

Hill, R.D.; Bäckman, L.; Wahlin, Ä.; Winblad, B.

Education and Occupation as Risk Factors for Dementias of Herod, B.; Thornby, J. 


\section{Original Research Articles}

Amyloid Precursor Protein Accumulation in Lewy Body

Dementia and Alzheimers Disease

Van Goal, D.; De Strooper, B.; Van Leuven, F.; Dom, R.

Bone Aluminium Content in Alzheimer's Disease

69

O'Mahony, D.; Denton, J.; Templar, J.; O'Hara, M.; Day, J.P.; Murphy, S.; Walsb, J.B.; Coakley, D.

Cerebrovascular Reactivity to Acetazolamide in (Senile)

73

Dementia of Alzheimer's Type: Relationship to Disease

Severity

Stoppe, G.; Schütze, R.; Kögler, A.; Staedt, J.; Münz, üffiEmrich, D.;

Rüther, E.

Diagnosis of Dementias Using Partial Least Squares D iscrimi- 83

nant Analysis

Gottfries, J.; Blennow, K.; Wallin, A.; Gottfhes, CG.

Twelve-Month Follow-Up Study of Regional Cerebral Blood

Tachibana, H.; Tornino, Y.; Kavvabata, K.; Sugita, M.; Fukuchi, M.

Delusional Misidentification and Subsequent Dementia:

A Clinical and Neuropathological St

Long-Term Estrogen Replacement Therapy in Female Patients 99 with Dementia of the Alzheimer Type: 7 Case Reports Ohkura, T.; Isse, K.; Akazawa, K.; Hamamoto, M.; Yaoi, Y.; Hagino, N.

Predictors of Mortality and Institutionalization in Alzheimer 108 Disease Patients 1 Year after DÜebarge from an Alzheimer Dementia Unit Bianchetti, A.; Scuratti, A.; Zanetti, O.; Binetti, G.; Frisoni, G.B.;

Magni, E.; Trabucchi, M.

\section{Review}

Quality of Life in Alzheimer's Disease Howard, K.; Rockwood, K.

113

Short Communication 
Visual Memory in Alzheimer Patients: Effects of Practice,

Retention Interval and Severity of Cognitive Decline Heun, R.; Bierbrauer, J. 


\section{Original Research Articles}

Beta-Amyloid Deposition in the Medial Temporal Lobe in

Elderly Non-Demented Brains and in Alzheimers Disease Armstrong, R.A.

Alzheimer Disease Amyloid Proteins Inhibit Brain Endothelial 126

Cell Proliferation in vitro

Grammas, P.; Botchlet, T.; Fugate, R.; Ball, M.J.; Roher, A.E.

Neuronal Number and Size Are Preserved in the Nucleus

basalis of Aged Rhesus Monkeys

Voytko, ML.; Sukhov, R.R.; Walker, L.C.; Breckler, S.J.; Price, D.L.; Koliatsos, V.E.

Clinical Diagnosis of Frontal Lobe Dementia and Alzheimer's 142

Disease: Relation to Cerebral Perfusion, Brain Atrophy and

Electroencephalography

Julin, P.; Wahlund, L-O.; Basun, H.; Persson, A.; Märe, K.;

Rudberg, U.

Quantitative EEG Mapping, Regional Cerebral Blood Flow, Rocchi, R.; Vatti, G.; Burgalassi, L.; Battistini, N.

Neuropathological Analysis of Dementia in a Japanese Lepro-

148 and Neuropsychological Function in Alzheimer's Disease Passero, S.;

arium

Goto, M.; Kimura, T.; Hagio, S.; Ueda, K.; Kitajima, S.-i.;

Tokunaga, H.; Sato, E

Neuropathological Diagnoses in Elderly Patients in Oslo:

162

Alzheimers Disease, Lewy Body Disease, Vascular Lesions Ince, P.G.; McArthur, F.K.; Bjertness, E.; Torvik, A.; Candy, J.M.; Edwardson, J.A.

Severity of Dementia Correlates with Loss of Broad-Band

169

Visual Cort ical Responses

Politoff, A.L.; Monson, N.; Stadter, R.P.; Hass, P.

Procedura! Memory and Parkinson's Disease 174

AUain, H.; Lieury, A; Quemener, V.; Thomas, V.; Reymann, J.-M.; Gandon, J.-M.

Announcement 


\section{Original Research Articles}

Transient Enhancement ofCholinergicNeurochemical 179

Markers Induced by NGF in Aged F344 Rats Santucci, A.C.; Kanof, P.D.; Haroutunian, V.

A Decrease in Neural Sialyltransferase Activity in Alzheimer's 185

Disease

Maguire, T.M.; Breen, K.C.

Familial Alzheimer's Disease and Cort ical Lewy Bodies:

191

Is There a Genetic Susceptibility Factor?

Lippa, C.F.; Smith, T.W.; Nee. L.; Robitaüle, Y.; Crain, B.;

Dickson, D.; Pulaski-Salo, D.; Pollen, DA.

Dietary Changes, Compulsions and Sexual Behavior in Fronto- 195

temporal Degeneration

Miller, B.L.; Darby, A.L.; Swartz J.R.; Yener, G.G.; Mena, I.

Leukocyte Hexokinase Activity in Aging and Alzheimer

Disease

Antuono, P.G.; RavaneUi-Meyer, J.; Nicholson, K.; Bloom A.S.

Atrophy of Hippocampal Formation Subdivisions Correlates 205 with Stage and Duration of Alzheimer Disease Bobinski, M.; WegKä» J.; Wisniewski, H.M.; Tarnawski, M.; Reisberg, B.; MIodzik, B.; de Leon, M.J.; Miller, D.C.

Synaptophysin Immunoreactivity Is Stable 36 h Postmortem 211 Liu, X.; Brun, A.

Reviews

The Cortical Neuritic Dystrophy of Alzheimer's Disease:

Nature, Significance, and Possible Pathogenesis Larner, A.J.

THA-Historical Aspects, Review of Pharmacological Proper-

225 ties and Therapeutic Effects Soares, J.C.; Gershon, S.

\section{Case Report}

Striatonigral Degeneration Combined with Olivopontocerebel- 235 lar Atrophy with Subcortical Dementia and Hallucinatory State Fukutani, Y.; Takeuchi, N.; Kobayashi, IC; Miyazu, K.; Yamaguchi, N.; Terada, T.; Nakamura, I.; Isaki. K. 
Tetraethylammonium-Induced Calcium Concentration

Changes in Skinlibroblasts from Patients with Alzheimer

Disease

Matsuyama, S.S.; Yamaguchi, D.T.; Vergara, J.; Jarvik, L.F.

Long-Term Effects of Tacrine on Regional Cerebral Blood

Flow Changes in Alzheimers Disease

Minthon, L.; Nilsson, K.; Edvinsson, L.; Wendt, P.E.; Gustafson, L.

Changes of the Relative Severity of Naming, Fluency and

Recall Impairment in the Course of Dementia of the

Alzheimer Type

Pollmann, S.; Haupt, M.; Kurz, A.

Effect of Seizures on Progression of Dementia of the

Alzheimer Type

Volicer, L.; Smith, S.; Volicer, B.J.

Eye Movement Dysfunction in Dementia of the Alzheimer

Type

Moser, A.; Kömpf, D.; Olschinka, J.

Temporal Quantification of Alzheimer's Disease Severity:

Time Index* Mode

Ashford, J.W.; Shan, M.; Butler, S.; Rajasekar, A; Schmitt, F.A.

Changes in a CSF Antigen Associated with Dementia

Carretero, MX; Hanington, CR.; Wischik, CM.

Review

Intravascular Malignant Lymphomatosis: A Cause of Subacute 286

Dementia

Treves, T.A.; Gadoth, N.; Blumen, S.; Korczyn, A.D.

Case Report

A Case of Alzheimer's Disease with Extensive Focal White

Matter Changes

Zahner, B.; Lang, C.J.G.; Engelhardt, A.; Thierauf, P.; Neundörfer, B. 
Heat Shock Protein 70 mRNA Levels in Mononuclear Blood Urakami, K.; Shimomura, T.; Takahashi, K.

Chromogranin A in Cerebrospinal Fluid: A Biochemical

Marker for Synaptic Degeneration in Alzheimer's Disease? Blennow, K.; Davidsson, P.; Wallin, A; Ekman, R.

Cognitive Performance after Small Strokes Correlates with

Ischemia, Not Atrophy of the Brain

Meyer, J.S.; Obara, K.; Muramatsu, K.; Mörtel, KR; Shirai, T.

EEG Findings in Dementia Are Related to the Parietal Lobe Syndrome

Edman, Ä.; Matousek, M.; Wallin, A

Number of Platelet Dense Granules Varies with Age, Schizo-

phrenia and Dementia

Kessler, A.; Shinitzky, M; Kessler, B.

Alzheimers Disease: Distribution of Changes in Intraneuronal 334

Lipopigment in the Frontal Cortex

Dowson, J.H.; Mountjoy, C.Q.; Cairns, M.R; Wilton-Cox, H.

Electroencephalographic Correlates of Periventricular White Becker, J.T.; Jungreis, CA; Rezek, D.: DeKosky, S.T.

Evidence of Blood-Cerebrospinal Fluid-Barrier Impairment in 348 a Subgroup of Patients with Dementia of the Alzheimer Type and Major Depression: A Possible indicator for Immunoactivation

HampelÄ; Müller-Spahn, F.; Berger, C; Haberl, A; Ackenheil, M.;

HoclcC.

\section{Case Report}

Cumulative Risk of Alzheimer-Like Dementia in Relatives of Autopsy-Confirmed Cases of Alzheimer's Disease Hocking, LB.; Breitner, J.C.S.
301 Cells from Patients with Dementia of the Alzheimer Type Wakutani, Y.;

306

330

343 Matter Lesions in Probable Alzheimer's Disease Lopez, O.L.; Brenner, R.P.; 
S. Karger

Medical and Scientific Publishers Basel • Freiburg $\square$ Paris $\bullet$ London New York $•$ New Delhi $\bullet$ Bangkok Singapore * Tokyo $\bullet$ Sydney 
DrugDosage

The authors and the publisher have exerted every effort to ensure lhat drug seleclion and dosage set forth in ihis texi are in accord with current recommendations and practice at the time of publication. However, in view of ongoing research, changes in govemraent regulations, and the con-stant flow of information relating to dmg therapy and drug reactions, the rcader is urged to check the package insert for each dmg for any change in indications and dosage and for added wamings and precautions. This is particularly impor-tant when the recommended agent is a new and/or infre-quently employed drug. 


\section{All rights reserved.}

No pari of this publication may be translated into other lan-guages, reproduced or ut il jzed in any form or by any means, electronic or mechanical, including photocopying, record-ing, microcopying, or by any information slorage and re-trieval System, without permission in writing from the publisher or, in the case of photocopying, direct payment of a specified fee to the Copyright Clearance Center (see 'Information for Readers and Subscribers').

(C) Copyright 1995 by S. Karger AG, P.O. Box, CH-4009 Basel (Switzerland) Printed in Switzerland on acid-free paper by Thür AG Offsetdruck. Pratteln 